\title{
Concrete evidence of change (Mt 3:1-12; Lk 3:8-14): The prophetic challenge of the Church to civil governance
}

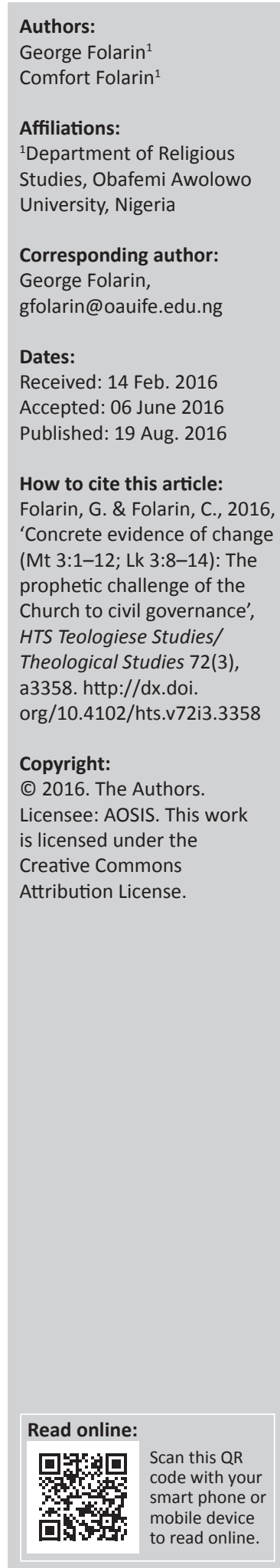

Democracy is not just about governing by the majority, but also respect and protection of the right of the weak and the minority. The tendency in any government is that the rights of the weak and the minority are denied them and their members are marginalised. In such a situation, what is the role expected of the church which perceives itself to be the mouth-piece of God to checkmate the abuse and promote the positive use of governance for the good of all? In this article, 'John the Baptist's ministry' is used as the springboard for this paper. Grammatical exegesis is adopted to study Matthew 3:1-2 and Luke 3:8-14. The paper integrates the message of John the Baptist in the context of the contemporary democratic experience in such a way that the prophetic voice of the church is heard afresh.

\section{Introduction}

Although all scholars agree that John the Baptist was an Old Testament prophet (Gaffney 2001:n.p.), less of them argue further that he was also a New Testament prophet (Hagner 2012:235). It is more convincing to the current researchers that John the Baptist, as a prophet, is strongly linked with the Old and the New Testaments (cf. Mt 11:13; Lk 16:16) (Hagner 2012:70). John, 'the voice crying in the wilderness', prepared the way for the emergence of Jesus on stage by calling his audience to repentance, initiating Jesus by baptism into his ministry, introducing him to the crowd as 'the Coming One', and by preaching a similar message with Jesus about the coming kingdom (Mt 1:2 cf. 4.17; Mk 1:15) (Hagner 2012:201; Holladay 2005:207). Finally, the ministry of the Baptist gave way to that of Jesus (Mk 1:2-5; cf. Quarcoophone 1985:85-86). The Baptist's message of moral change as evidence of spiritual change, and his presentation of Jesus as the judge par excellence over the unrepentant forcefully negate the claim of many to be religious without manifesting evidence of positive change in their lives. The current researchers examine the message of 'The Baptist' on change as a paradigm for the church in its combat against ungodliness in the public space, especially among its members. The challenge that Jesus would ultimately judge evil and ungodliness is also applied to discourage unethical behaviours among Nigerians.

\section{The basis of change in the proclamation of John the Baptist (Mt 3:2)}

Abogunrin observes, several years ago, 'We live in an age of secular humanism which includes explicit denial of God ... The humanists accept moral standard for its own sake but reject theological ethics' (Abogunrin 1986:5). Humanists are of the view that the human being is a mature moral agent who needs no divine help to know or do what is right or wrong. This view is exclusively anthropocentric, and it poses danger by interpreting John the Baptist merely as a preacher of morality without underscoring the fact that his ethical challenge was a product of his spiritual concern. To correct this error, the basis of John's challenge to morality in Matthew 3:2 is examined below.

The text (Mt 3:2) shows that the foundational message of John the Baptist to the crowd is

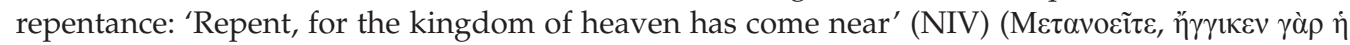

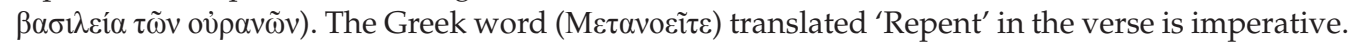
The Baptist's call for repentance was primarily directed to his immediate audience. The command to repent in Matthew 3:2 is for a decision to turn the whole person around. Toussaint (1980) rightly comments:

In the New Testament [repentance] ... indicates a complete change of attitude, spiritual and moral, towards God. The primary meaning involves a turning to God which may indeed make a person sorry for his sins, but that sorrow is a by-product and not the repentance itself. (p. 60) 
Verbrugge clearly explains the Greek word translated, 'repent', used by John the Baptist in his challenge. 'The NT uses $\mu \varepsilon \tau \alpha v o \varepsilon \omega$ ['repent' - Mt 3:2; Lk 10:13] ... rather than $\dot{\varepsilon} \Pi 1 \sigma \tau \varepsilon \varphi \omega \omega$ ['turn' - Mt 9:22; 'convert' - Jn 12:40], [to indicate] ... that the NT does not stress the concrete outward turning ... but the thought, the will, the vous' (Verbrugge 2000:367; cf. Wigram 1980:287, 488). It is thus difficult to explain John the Baptist's call to 'repent' in Matthew 3:2 without basing the moral on spiritual change. John uses the conjunction, 'for' ( $\gamma \grave{\alpha} \rho)$ in Matthew 3:2 in illative sense to introduce the reason for the urgency of his call: something uncommon is about to happen (cf. Dana \& Mantey 1957:243).

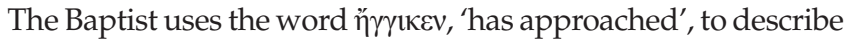
the closeness of the intervention (Perschbacher 1990:112). The word $\eta^{\prime} \gamma$ $1 \kappa \varepsilon v$ is used metaphorically in Matthew 3:2. Preisker (1965:330-331) observes, '[...] the distinctive feature of both

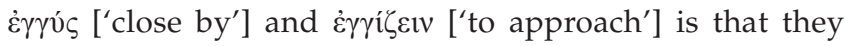
express ... the eschatological fulfilment, of the great turning point in world history, of the coming of the kingdom of God directly into the present as the miracle of God'. He is also

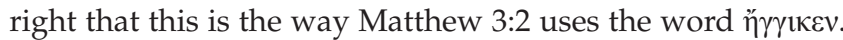
The perfect tense of the Greek verb, $\eta^{\prime} \gamma \gamma(\kappa \varepsilon v$ translated, 'to approach' in the NT may actually refer to 'extreme closeness' (cf. Arndt \& Gingrich 1957:212). This probably informs the NIV's translation of the word as 'has come near'. Toit should be taken seriously too when he affirms, 'the perfect the opening proclamation of John the Baptist ... (cf. Mt 3:2; $4: 17$ and 10:7), should be understood in the sense of 'has arrived', 'is here' (Toit 2000:552).

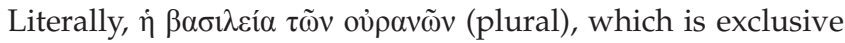
to Matthew, is the plural form of heavens. The plural form ('of heavens') is a typical 'Jewish reverential periphrasis for the divine name' (Toit 2000:348; cf. Lk 15:18; Evans 1962, 3:18; Vos 1948a:376-378). What Matthew calls the 'kingdom of heavens' other Gospels call the 'kingdom of God'. Matthew uses the phrase, 'Kingdom of heavens', 32 times.

In a way, the kingdom of heaven is the reign of God over the whole world from the time of creation whether this is recognised by all or not (Evans 1962, 3:17-18). Although the Old Testament neither uses the phrase 'kingdom of heaven' nor 'kingdom of God', the idea that Yahweh is the ruler is found throughout the Prophets. Ladd (1993) states:

There is a twofold emphasis on God's kingship. He is frequently spoken of as the King, both of Israel (Exod 15:18; Num 23:21; Deut 33:5; Isa 43:15) and of all the earth (2 Kings 19:15; Isa 6:5; Jer 46:18; Ps 29:10; 99:1-4). Although God is now King, other references speak of a day when he shall become King and shall rule over his people (Isa 24:23; 33:22; 52:7; Zeph 3:15; Zech 14:9ff.). This leads to the conclusion that while God is the King, he must also become King, i.e., he must manifest his kingship in the world of human beings and nations. (p. 58)

A New Testament scholar insightfully points out:

It is remarkable how often reflections on the kingdom of God in the New Testament simply ignore the importance of the qualifying genitive 'of God'. Moreover, this ['of heaven'] is not simply a possessive genitive or a genitive of origin; it is subjective, indicating that God is actively at work here. It therefore qualifies the kingdom as God-centred, as God-determined, as the product of God's personal being and activity. (Toit 2000:548)

This is a timely warning and is helpful in the interpretation of the selected texts and the understanding of the concept of the kingdom of heaven.

Crossan holds John the Baptist to be an apocalyptic prophet who was 'preparing his followers for the imminent advent of God as the Coming One' (Crossan 1991:259). The current writers disagree with Crossan that the Baptist's story here is ahistorical. John's announcement that the kingdom of heaven has drawn near indicates that the reign of heaven is about to take a new turn through Jesus Christ that he refers to as the Coming One. This is most reasonable if the initial recipients of the Gospel were Jews (Hagner 2000:262). While there are strong arguments that the Evangelist wrote to Jews, many NT scholars do not hold this to be exclusive. It is important to note that John the Baptist's call to repentance is premised on the nearness of 'the kingdom of heaven'.

The announcement by John the Baptist of the closeness of the kingdom of heaven could therefore only mean that a new phase of heaven's or God's rule was about to break in with the coming of Jesus. The new phase of the kingdom, which is most likely a shortened form of the kingdom of heaven in Matthew is thus eschatological with both inaugurated (e.g., Mt 6:33) and futuristic (e.g., Mt 4:17) aspects. Saucy puts it thus, 'the kingdom is at hand (Mt 4:17) and, in fact, is already present in the power of Christ (Mt 12:28)' (Saucy 1972:58). The inaugurated or incipient eschatological aspect began with the ministry of Jesus who is regarded as the king of the kingdom (cf. Lk 17:21). The futuristic aspect is the time of finality that can be described as the time of consummation of the kingdom (McKnight 1992:535-536). The field of eschatology is vast, complex, and debatable, and unfortunately, interpreters' theological leanings do influence their interpretations. One school argues that Jesus the Christ is the Messianic king of God's kingdom, but that a time is coming when he would hand over the rule to God the Father: 'Christ ${ }^{24}[\ldots]$ will come [and] ... hand over the kingdom to God the father after he has destroyed all dominion, authority and power. ${ }^{25}$ For he must reign until he has put all his enemies under his feet' (1 Cor 15:24-25).

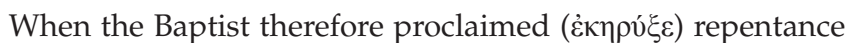
'for' (because?) ( $\gamma \grave{\alpha} \rho)$ the kingdom of heaven has come close, the intended meaning is that the ruler and judge of righteousness is around and no one can afford to live as if all things would remain the same. Bura similarly views John's preaching of repentance as 'eschatologically motivate(d) ... (by his awareness of) the nearness of the kingdom of heaven through the Messiah' (Bura 2009:275).

\section{The evidence of change required in the proclamation of John the Baptist (Mt 3:2, 6-12)}

The closest connection between prophetic call to repentance and positive evidence of change in the New Testament is 
in Matthew 3:2, 8 - 'Repent ye ... [and] bring forth ... fruit

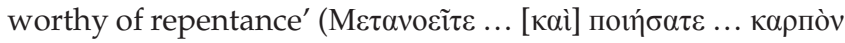

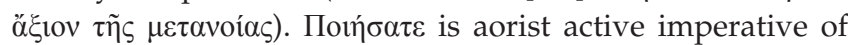
погє́ in which the action is viewed as a whole, without regard for the internal make-up of the action' (Wallace 2000:317). Viewed in Constative sense, the emphasis of the word,

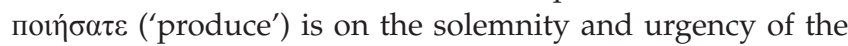
action. It is characteristic of Constative use of aorist imperative that the urgency of the occasion is heightened just as it is here (Wallace 2000:318).

Arndt and Gingrich define поє⿱㇒㠯 in line with its use in Matthew 3:2, 8, as 'send out', 'produce', 'bear', and 'yield' (Arndt \& Gingrich 1957:688). Пои́б $\alpha \tau \varepsilon$... карпо̀v ('bear fruit') is a Semitic idiom which describes positive outcome, while a'slos means 'worthy', or 'in agreement with'. Thayer, on the other hand renders " $\alpha \xi 10 \varsigma$ in Matthew 3:2, 8, 'befitting, congruous, or corresponding' (Thayer 1886:52). Matthew 3:8 has led some scholars to turn John the Baptist merely to a social crusader, a humanist, and a natural ethicist by purging or underplaying his message of its religious or spiritual contents (Usman 2007:453). If John the Baptist is however considered primarily as a prophet of Israel, whose main concern was the spiritual change of his people, then his ethical call would be meaningful as an outcome of spiritual change. The Baptist would thus have placed his ethical call in the context of the kingly reign through the Messiah (Hock 1996:39). That is the position of the current authors.

John the Baptist posits, in Matthew's account, two observable evidence to know if repentance has taken place or not: Baptism and moral fruitfulness (Mt 3:6, 8). The fact that 'all the Judea and all around the country of Jordan' went to John for baptism indicates that they accepted his message. In that era, baptism was not only practiced for proselytes, 'it was also carried out for remedial and purifying purposes'

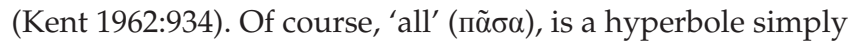
indicating that many of John's hearers submitted for baptism, most likely as an evidence of their repentance. There are reputable scholars who do not interpret this baptism as symbolic. They see in the ritual itself the ability to actually effect change (Kent 1962:934). That is not the position adopted here. While John's baptism needs not be endowed with Christian interpretation, its acceptance is indicative of obedience to the prophetic preaching of John.

The other evidence which the Baptist called for is producing 'fruit in keeping with repentance' (Mt 3:8). To this the Baptist adds the warning that there is already an axe laid at the root of the unproductive tree. This is symbolic of divine judgement, and the Baptist in this figure presents the Messiah as the judge that is around to reward his hearers. Retribution was also likely hinted at as the work of the Messianic king when John presented Jesus as the baptiser 'with the Holy Spirit and fire' (Mt 3:11).

It can be deduced, therefore, from Matthew 3:11, 12 that the work of the coming Messiah involves judgment: ${ }^{\prime 11} \mathrm{He}$ will baptise you with ... fire. ${ }^{12}$ His winnowing fork is in his hand, and he will clear his threshing floor ... burning up the chaff with unquenchable fire' (Mt 3:11, 12; cf. Allen 1912:26). Hence the emphasis of John the Baptist is that the moral change God demands is based on one's relationship with God (Anderson 1999:61).

\section{Examples of the change required by John the Baptist (Lk 3:11-14)}

While Matthew records John's call for change and his demand for evidence of that change, only Luke records the examples of the changes required. The source of Luke 3:11-14 is therefore ' $L$ '. The three representative groups which John the Baptist addressed in his challenge in the wilderness were 'The crowds' who were peasants; 'the tax collectors' who were Jewish agents of the Roman Empire; and 'the soldiers' who were guardians of imperial order (Walaskay 1983:28). The Baptist told 'the crowds' (oi ö $\chi \lambda \mathrm{or}$ ) that whoever had extra garments or food should share with those who had none. If Arndt and Gingrich are correct, the phrase, 'two garments'

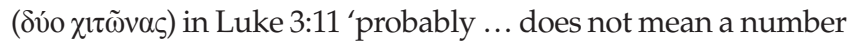
of shirts but extra clothes' (Arndt \& Gingrich 1957:890). Plummer points out, 'the $\chi \imath \omega \dot{v}$ was the under and less necessary garment, distinguished from the upper and almost indispensable i $\mu$ ó $\tau 1 v^{\prime}$ which was the outer garment (Plummer

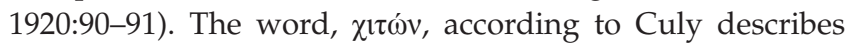
'[...] a garment worn next to the skin and under a cloak, like a shirt, but which would have been longer than a Western style shirt' (Culy, Parson \& Stigal 2010:108). If the poorest, at that time, only had one tunic, then anyone with two tunics had more than necessary (Keener 1993:196). Secondly, the Baptist requested 'the crowds' to share food with those who were poorer. Some implications of the command here are that hoarding is not godly and that even the poor can afford to be generous to the poorer; and the repentant are to share what they have with one another (cf. Barclay 2001:34). These were to the Baptist, evidence of true repentance.

The Baptist exhorted the tax collectors who came for baptism, most likely as evidence of repentance (Lk 3:13), not to collect more tax than they were required to collect. The tax collectors were renowned to work for the oppressor, the enemy, the Romans and were viewed as traitors who would sell out their honour for the love of money. Again, tax collectors were renowned for cheating their fellow citizens wherever they could (Wilson 1985-2016:n.p.). These tax collectors were either agents of Caesar or Herod to collect custom duties. They were exhorted to show the genuineness of their repentance 'by not abusing their position and by never extorting excessive taxes for their own enrichment' (Geldenhuys 1950:139; cf. Isaak 2006:1236). The Baptist shows that repentance may not call for change of job, but doing that job in the fear of God. That reveals further that spiritual change is expected to manifest in social relationship.

The Baptist instructed the final group, the soldiers, not to extort money from the public, not to falsely accuse the citizenry, and to be satisfied with their salaries (Lk 3:11-14). 
The precise identity of these soldiers is not certain. The argument rests among the Temple's, Herod's and Caesar's soldiers. The soldiers were however most likely the soldiers of the Roman Emperor. The pronouncements of John the Baptist in Luke 3:11-14 are clearly ethical but are not exclusively so. They are premised on prior repentance. Luke 3:11-14 is a popular text to Nigerian biblical scholars because of its moral challenge useful for promoting national development. Usman and Kwasau exemplify scholars who employ the text in that way but while Usman (Usman 2007:449-456) completely skips John's emphasis on spirituality, Kwasau fairly includes it (Kwasau 2009:266-273).

Commenting on Luke 3:10-14, Gilmour opines that the list of the ethical demands from John was just a sample (Gilmour 1980:75). The demands were not meant to be exhaustive. These ethical demands, within John's milieu, were also not radical in nature (Bowie 1980:74; Gilmour 1980:75), but in the fearless way they were delivered - for John the Baptist fearlessly confronted his audience across social status.

\section{Prophetic challenge to governance: The Nigerian case}

In the contemporary Nigerian society, the relationship between religion and politics is being abused by both politicians and religious leaders. Ikhariale in connection with this fact states, 'Of particular interest ... today is the unrestrained deployment of religious sentiments into ... campaigns' (Ikhariale 2015:n.p.). Many politicians in the country use religion when making political statements. Election seasons have become the time politicians employ religion mostly by visiting religious centres to win the support of adherents of such religions in their search for political power (Punch Editorial 2015:n.p.). According to Temionu, some clerics even almost turned themselves to party agents by canvassing for named candidates and political parties in 2014 election in Nigeria (Temionu 2015:n.p.). The worst example of religious interference in politics cum governance is the despicable issue of Boko Haram. Despite the denial of some, many in the country are of the view that the Boko Haram insurgency is largely fuelled by religious extremism (Kadivar 2014:n.p.). Kadivar notes that both the Lord's Resistance Army in Uganda and the Boko Haram in Nigeria use religion as a political weapon.

One Archbishop Emma D. Okafoagu of the 'New Covenant of God Mission' predicted, and in a news conference announced, that the then President of Nigeria had been ordained by God for another term ('God has Anointed Jonathan for 2nd Term' 2015:n.p.). Although Okafoagu's prediction failed, K.L. Spark notes nevertheless that religion has been a tool of propaganda for politics for a very long time. Sparks (2005) comments:

[...] the account of David's rise to power reminds us of Near Assyrian propaganda. David is presented as a pious and divinely elected warrior-king who possessed an almost superhuman respect and love for his Israelite enemies ... the story of David's rise and succession narrative were propagandistic apologies composed to promote the regimes of David and Solomon. (p. 821, 823)
Okafoagu exemplifies the church cleric who is a vanguard for politicians, and whose role embarrasses the church.

John the Baptist was a prophet not only because he called himself so (Mt 3:2) but others also recognised him to be so (Lk 7:26-28). He was 'a prophet who's not afraid to expose the moral improprieties of the political leaders of his day, even at the risk of his own death' (Tatum 1994:96). McLennan (2005:n.p.) postulates that the church can learn to be prophetic from the Baptist by challenging political authority when it acts immorally and/or in derogation of fundamental values, and by exposing moral inappropriateness of political rulers on behalf of the helpless. McLennan, builds on John the Baptist's criticism of Herod who took over his brother's wife unworthily (Mt 14:3-11). The debate surrounding the identity of the Herod who married Herodias is outside the focus of this work. The conclusion of Hoehner is supported by the current writers, 'there is no over-riding reason for not considering the Herod of Josephus and the Philip of Matthew and Mark to be one and the same person' (Hoehner 1980:136). Another relevant point is that John was a prophet of justice. Justice is a dominating theme not only in the Old Testament, the idea also dominates the message of John the Baptist. The 'prophets and other charismatic leaders ... were the symbols of the Jewish collective consciousness, [and they] stood as guardians of tzedek [justice]' (Schoenfeld 1989:237) Although John the Baptist does not use the term, 'justice', the concept of 'righting' the wrong done to the weak and the poor permeates his proclamation. Vos limits John's call to repentance from the 'sins of social and economic injustice' (Vos 1948b:110). If John comes to prepare the people to receive the Messiah (the voice of the one crying in the wilderness, 'prepare the way for the Lord'), then it is unlikely that John's calls for repentance is only from social and economic injustice. The current researchers see justice in the Old Testament as that which concerns the abuse of power assessed on the basis of Yahweh's covenantal demand, while in the New Testament justice which is conveyed by the word righteousness, 'assumes a just relationship with God and then with others' (cf. Kunst 1983:111). It is a product of love which results from an earlier encounter with the divine. The prophetic declaration of John the Baptist on justice is thus a powerful challenge to the church to dare its contemporary to repent from its sinful ways (McLennan 2005:n.p.).

The contexts of John's call in the selected texts show that the prophet expected true religious transformation to show evidence of positive inter-personal relationship with others. In its Jewish milieu, a prophet was primarily a spokesperson for God. Folarin underscores this in his definition, 'a prophet is an authorized spokesman for God in whose words a divinely communicated power resides' (Folarin 2015:11). So, if the main work of the prophet is to speak for God, then calling on his hearers to return or rededicate themselves to God is basic to the prophet's ethical challenge, and this is a lesson that the church in Nigeria needs to learn from John the Baptist.

The Old Testament prophets base the moral criticism of their contemporaries on the covenant standard of Yahweh (Folarin \& Olanisebe 2014:243). The prophets however use 
the standard derived from the general revelation to criticise non-Jewish nations (Folarin \& Olanisebe 2014:243). John the Baptist stands in this prophetic tradition and should be interpreted in that light. Like John the Baptist, the church in Nigeria needs to use a biblical standard to evaluate the governors, their policies, and the governed. The church would need to avoid politicking. The prophetic responsibility of the church in governance should primarily be spiritual oversight. Where policy makers are Christians, the church has the additional opportunity to challenge them as individuals to dedication to God and to commitment to the service of others to God's glory.

Although it is recognised by many that religion has been politicised to a great extent in Nigeria (Aruwa n.d.:n.p.), the situation needs not be so. Manipulating governance to advance one religion over the other is a questionable but common practice in certain parts of the country. Many politicians have used religion to ascend political posts, while many others have used political power to promote their brand of religion. This is are unworthy and dangerous. In fact, one factor that led to the emergence of Christian Association of Nigeria was the oppression of the church in some parts of Nigeria by members of a particular religion who use state power to suppress members of some other religions both in employment opportunity and permission to erect worship centres (Enwerem 1995:75-97). Of course, Enwerem suggests two other reasons for the emergence of CAN (Cf. Kaduna Religious Riot ' 87 n.d.). The booklet by CAN states that the abuse of electronic and print media heightens conflict among religions (Kaduna Religious Riot '87 n.d.:5), while the misuse of security agents turns members of one religion against the others religions in Nigeria (Kaduna Religious Riot' 87 n.d.:6). While redressing injustice is arguably an important role of the prophet, it is not his primary role. The church can learn from John the Baptist that to be prophetic, its primary role would need to remain the restoration of humans' relationship with God. To the church, both its primary and secondary responsibilities are important and in its prophetic challenge, its primary responsibility should not be sacrificed for the secondary.

\section{Conclusion}

Although Ituma forcefully points out that Christians need to participate in politics (Ituma 2009:n.p.), it should be on an individual level. Even at that, it is not advisable for church pastors to be patrician. Just as John the Baptist's call begins with the need for personal repentance, but moves beyond it to the social implication of faith, so should the prophetic challenge of the church be holistic. As Nigeria, for example, is recognised by many as a very religious country, it is necessary that the church in that country first challenges its members to live out the implications of their faith in a public sphere by being just and by demanding justice from others. Again, the church should enlighten others in the society that life of justice is a vital evidence of true religiosity. Finally, the church needs to announce God's judgment on the corrupt and unjust, irrespective of political and religious status.
Corruption and injustice should be interpreted as evidence of peoples' failure to sincerely commit themselves to God. The church in its search for relevance in Nigeria should therefore not forsake its spiritual identity.

\section{Competing interests}

The authors declare that they have no financial or personal relationships which may have inappropriately influenced them in writing this article.

\section{Authors' contribution}

G.O.F. designed and headed the research work and interpreted the relevant Bible texts. C.O.F. researched the relation of religion with politics in Nigeria.

\section{References}

Abogunrin, S.O., 1986, 'Religion and ethics', in S.O. Abogunrin (ed.), Ibadan religious studies series I: Religion and ethics in Nigeria, pp. 1-13, Daystar, Ibadan.

Allen, W.C., 1912, International critical commentary: A critical and exegetical commentary on the Gospel according to S. Matthew, edited by S.R. Driver, A. Plummer \& C.A. Briggs, 3rd edn., T and T Clark, Edinburgh.

Anderson, B.W., 1999, Contours of Old Testament theology, Fortress, Minneapolis, MN.

Arndt, W.F. \& Gingrich, F.W., 1957, A Greek-English Lexicon of the New Testament and other early Christian literature, The University of Chicago, London.

Aruwa, S.P., n.d., 'When will religion and politics save Nigeria?' viewed from http:// www.gamji.com/article5000/NEWS5290.htm

Barclay, W., 2001, The Gospel of Luke, Westminster John Knox, Louisville, KY.

Bowie, W.R., 1980, 'The Gospel according to St. Luke: Exposition', in G.A. Buttrick et al., (eds.), The Interpreter's Bible, vol. 8, pp. 24-127, Abingdon, Nashville, TN.

Bura, D.O., 2009, 'John the Baptist's injunctions to public officers: A challenge to public officers in Nigeria', in S.O. Abogunrin (ed.), Biblical studies and leadership in Africa, pp. 274-282, NABIS, Ibadan.

Crossan, J.D., 1991, The Historical Jesus: The life of a Mediterranean Jewish Peasant, Harper, San Francisco, CA.

Culy, M.M., Parson, M.C. \& Stigal, J.J., 2010, Luke: A handbook on the Greek text, Baylor University, Waco, TX.

Dana, H.E. \& Mantey, J.R., 1957, A manual grammar of the Greek New Testament, The Macmillan, Toronto.

Enwerem, I.M., 1995, A dangerous awakening: The politicization of religion in Nigeria, IFRA, Ibadan.

Evans, O.E., 1962, 'Kingdom of God', in G.A. Buttrick et al., (eds.), The interpreter's dictionary of the bible, vol. 3, pp. 17-26, Abingdon, Nashville, TN.

Folarin, G.O., 2015, Studies in Old Testament prophecy, ACTS, Bukuru.

Folarin, G.O. \& Olanisebe, S.O., 2014, 'Threat of judgement in Amos and its lessons for Nigeria', European Scientific Journal 10(26), 243-261.

Gaffney, M., 2001, 'St. John the Baptist: Last of the Old Testament prophets', in Exhibit New, viewed from http://www.vaticanexhibit.com/stories/011502/ new_johnthebaptist.shtml

Geldenhuys, N., 1950, Commentary on the Gospel of Luke, Marshall, Morgan and Scott, London.

Gilmour, S.L., 1980, 'The Gospel according to St. Luke: Introduction and exegesis', in G.A. Buttrick et al., (eds.), The interpreter's bible, vol. 8, pp. 3-434, Abingdon, Nashville, TN.

'God has Anointed Jonathan for 2nd Term - Arch Bishop Okafoagu', 2015, The Sun, viewed from http://sunnewsonline.com/new/god-has-anointed-jonathan-for2nd-term-arch-bishop-okafoagu/

Hagner, D.A., 2000, 'Matthew', in T.D. Alexander et al., (eds.), New dictionary of Biblical theology, pp. 262-267, IVP, Downers Grove, IL.

Hagner, D.A., 2012, The New Testament: A historical and theological introduction, Baker Academic, Grand Rapids, MI.

Hock, E.C., 1996, 'Theology and ethics', Reformation and Revival 5(4), 32-56.

Hoehner, H.W., 1980, Herod Antipas: A contemporary of Jesus, Zondervan, Grand Rapids, MI.

Holladay, C.R., 2005, A critical introduction to the New Testament, Abingdon, Nashville, TN.

Ikhariale, M., 2015, 'Leave God out of politics', Punch, viewed from http://www. punchng.com/columnists/trivia-constitutional/leave-god-out-of-politics/

Isaak, P.J., 2006, 'Luke', in T. Adeyemo (ed.), Africa Bible commentary, pp. 1229-1276, WorldAlive, Nairobi. 
Ituma, E.A., 2009, 'Religion and Partisan politics in Nigeria: A challenge to the committed Christian', Professor Bassey Andah Journal of Cultural Studies, viewed from http://www.academicexcellencesociety.com/religion_and_partisan_politics_ in nigeria.html

Kadivar, M., 2014, 'The Haram operations of Boko Haram', ISLAMiCommentary, viewed from http://islamicommentary.org/2014/05/the-haram-operations-of-bokoharam/

Kaduna religious riot '87: A catalogue of events by CAN, n.d., CAN (Christian Association of Nigeria), Kaduna.

Keener, C.S., 1993, The IVP Bible background commentary, InterVarsity Press, Downers Groove, IL.

Kent, H.A., 1962, 'Matthew', in C.P. Pfeiffer \& E.F. Harrison (eds.), The Wycliffe Bible commentary, pp. 929-985, Moody, Chicago, IL.

Kunst, T.J.W., 1983, 'The Kingdom of God and social justice', Bibliotheca Sacra 140(558), 108-116

Kwasau, J.N., 2009, 'John the Baptist's injunctions to public officers: A challenge to the People of Nigeria', in S.O. Abogunrin (ed.), Biblical studies and leadership in Africa, pp. 266-273, NABIS, Ibadan.

Ladd, E.G., 1993, A theology of the New Testament, revised edition, edited by D.A. Hagner, Eerdman, Grand Rapids, MI.

McKnight, S., 1992, 'Gospel of Matthew', in J.B. Green et al., (eds.), Dictionary of Jesus and his Gospels, pp. 526-541, IVP, Downers Gove, IL.

McLennan, D.S., 2005, 'The message of John the Baptist', viewed from http://web. stanford.edu/group/religiouslife/cgi-bin/wordpress/wp-content/uploads/ sermons/2005/sermon_12-04-2005_McLennan.pdf

Perschbacher, W.J., 1990, The New analytical Greek Lexicon, Hendrickson, Peabody, MA

Plummer, A., 1920, The international critical commentary: A critical and exegetical commentary on the Gospel according to St. Luke, Charles Scribner's Sons, New York.

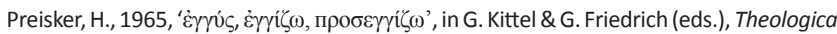
dictionary of the New Testament, vol. II, pp. 330-3336, Wm B. Eerdman, Grand Rapids, MI.

Punch Editorial, 2015, 'Limit of religious and ethnic politics', Punch, viewed from http://www.punchng.com/editorials/limits-of-religious-and-ethnic-politics/
Quarcoophone, T.N.O., 1985, The synoptic Gospels, African University Press, Ibadan. Saucy, R., 1972, The Church in God's Kingdom, Moody, Chicago, IL.

Schoenfeld, E., 1989, 'Justice: An illusive concept in Christianity', Review of Religious Research 30(3), 236-245. http://dx.doi.org/10.2307/3511508

Sparks, K.L., 2005, 'Propaganda', in B.T. Arnold \& H.G. Williamson (eds.), Dictionary of the Old Testament historical books, pp. 821-825, IVP, Leicester.

Tatum, W.B., 1994, John the Baptist and Jesus: A report of the Jesus seminar, Polebridge, Sonoma, CA.

Temionu, T., 2015, 'Between religion and political soothsaying', Punch, viewed from http://www.punchng.com/opinion/between-religion-and-political-soothsaying/

Thayer, J.H., 1886, A Greek-English Lexicon of the New Testament, American Book, New York.

Toit, A.B. du, 2000, 'The Kingdom of God in the Gospel of Matthew', Skirf en Kerk 21(3), 545-563. http://dx.doi.org/10.4102/ve.v21i3.639

Toussaint, S.D., 1980, Behold the king: A study of Matthew, Multnomah, Portland, OR.

Usman, D.B., 2007, 'John the Baptist's attack on corruption: An appraisal of Luke $3: 10-14{ }^{\prime}$, in S.O. Abogunrin (ed.), Biblical studies and corruption in Africa, pp. 449-456, NABIS, Ibadan.

Verbrugge, V.D., 2000, The new international dictionary of theology, abridged edition, Zondervan, Grand Rapids, MI.

Vos, G., 1948a, Biblical theology: Old and New Testaments, Wm B. Eerdman, Grand Rapids, MI, pp. 376-378.

Vos, J.G., 1948b, 'The social and economic responsibility of the visible church', Westminster Theological Journal 10(2), 107-138.

Walaskay, P.W., 1983, 'And so we came to Rome' the political perspective of St. Luke, Cambridge University, Cambridge.

Wallace, D.B., 2000, The basis of New Testament syntax: An intermediate Greek grammar, Zondervan, Grand Rapids, MI.

Wigram, G.V., 1980, The Englishman's Greek concordance of the New Testament, Zondervan, Grand Rapids, MI.

Wilson, R.F., 1985-2016, 'Produce the fruit of repentance', viewed n.d. from http:// www.jesuswalk.com/lessons/3_7-14.htm 